\title{
Analisa Konfigurasi Jaringan FTTH dengan Perangkat OLT Mini untuk Layanan Indihome di PT. Telkom Akses Witel Semarang
}

\author{
Puri Muliandhi' ${ }^{1}$, Erlian Husna Faradiba ${ }^{2)}$, dan Bayu Adi Nugroho ${ }^{3)}$ \\ 1) Jurusan Teknik Elektro Universitas Semarang, ${ }^{2,3)}$ PT Telkom Akses Witel Semarang \\ ${ }^{1)}$ Jl. Soekarno Hatta, Tlogosari Kulon, Kec. Pedurungan, Kota Semarang, Jawa Tengah 59160, \\ 2,3) Jl. Singotoro No. 20, Jomblang, Kec. Candisari, Kota Semarang, Jawa Tengah 50256 \\ e-mail: puri@usm.ac.id ${ }^{1)}$, erlian.ehf@gmail.com ${ }^{2)}$, bayuadinugroho76@gmail.com $^{3)}$
}

\begin{abstract}
The development of increasingly sophisticated technology follows the needs of the community, one of them in the telecommunications world is FTTH (Fiber to the Home) which is an optical signal delivery format from the center of the provider to the homes of costumers by using optical fiber as a medium of delivery. Delivery by using this FTTH technology can save costs and provide better service to customers. The study was conducted by interview and observation methods with network objects and FTTH components belonging to Telkom Semarang and through the literature method by searching some literature. FTTH configuration starts with the ONT to rosette connected using a patchcord cable then from rosette to OTP using an indoor cable then from OTP to ODP outside the home is connected using a dropcore cable. ODP itself is the result of the distribution of distribution cables/ aerial cables leading to ODC. ODC to STO/FTM/ODF using feeder cable. FTTH network is very effective to use, because it can use triple play services (telephone, internet and IPTV) with just 1ONT/ modem at the customer's side.
\end{abstract}

Keywords : FTTH, Configuration, Telkom, OTP.

\begin{abstract}
ABSTRAK
Perkembangan teknologi yang semakin canggih mengikuti kebutuhan masyarakat, salah satunya dalam dunia telekomunikasi yaitu FTTH (Fiber to the Home) yang merupakan format penghantaran sinyal optik dari pusat penyedia (provider) ke rumah-rumah pelanggan dengan menggunakan fiber optik sebagai media penghantar. Penghantaran dengan menggunakan teknologi FTTH ini dapat menghemat biaya dan mampu mengurangkan biaya operasi serta memberikan pelayanan yang lebih baik kepada pelanggan. Penelitian dilakukan dengan metode wawancara dan pengamatan dengan objek jaringan dan komponen FTTH milik Telkom Semarang serta melalui metode kepustakaan dengan pencarian beberapa literatur. Konfigurasi FTTH dimulai dengan ONT ke Roset dihubungkan menggunakan kabel patchcord kemudian dari Roset menuju ke OTP menggunakan kabel indoor lalu dari OTP menuju ke ODP yang berada di luar rumah dihubungkan menggunakan kabel dropcore. ODP itu sendiri merupakan hasil pembagian kabel distribusi/kabel udara yang menuju ke ODC. Lalu dari ODC menuju STO/FTM/ODF menggunakan kabel feeder. Jaringan FTTH sangat efektif dipakai, karena pelanggan dapat menggunakan layanan triple play ( telepon, internet dan IPTV ) hanya dengan 1ONT/ modem saja disisi pelanggan.
\end{abstract}

Kata Kunci: FTTH, Konfigurasi, Telkom, OTP.

\section{Pendahuluan}

$\mathrm{K}$ ebutuhan masyarakat akan infomasi merupakan salah satu faktor yang mendorong sistem telekomunikasi untuk berkembang mengikuti kebutuhan masyarakat. Dengan berkembangnya teknologi, jaringan telekomunikasi juga semakin canggih. Salah satu bentuk perkembangan teknologi di dunia telekomunikasi adalah FTTH (Fiber To The Home). Keberadaan FTTH berhasil menjadi jembatan informasi yang lebih cepat dan efisien. FTTH merupakan suatu format penghantaran sinyal optik dari pusat penyedia (provider) ke rumah-rumah pelanggan dengan menggunakan fiber optik sebagai media penghantar. Saat ini jaringan lokal akses tembaga sudah mulai tergantikan dengan fiber optik. Hal ini dilakukan karena jaringan akses tembaga hanya mampu menyalurkan maksimal hingga 4 Mbps, sehingga perlu dilakukan modernisasi. Tujuannya agar mampu menyalurkan bandwidth hingga 100 Mbps dengan menggunakan teknologi Gigabit Passive Optical Network ( GPON ). Prinsip kerja dari GPON itu sendiri ketika data atau sinyal dikirimkan dari Optical Line Terminal ( OLT ) yang merupakan sub sistem dari Optical Access Network yang berdasarkan teknologi Passive Optical Network ( PON ), berfungsi sebagai antar muka sentral dengan jaringan yang dihubungan ke satu atau lebih jaringan distribusi optik. Pada prinsipnya Passive Optical Network ( PON ) adalah salah satu jenis teknologi fiber optic yang menggunakan konfigurasi sistem point to multipoint.

\section{A. Fiber Optik}

Fiber optik adalah saluran transmisi atau sejenis kabel yang terbuat dari kaca atau plastik yang sangat halus dan lebih kecil dari sehelai rambut, serta dapat digunakan untuk mentransmisikan sinyal cahaya dari suatu tempat ke tempat lain. Sumber cahaya yang digunakan biasanya adalah sinar laser atau light emitting diode (LED). Kabel ini berdiameter lebih kurang 120 mikrometer. Cahaya yang ada di dalam fiber optik tidak keluar karena indeks bias dari kaca lebih besar daripada 
indeks bias dari udara, karena laser mempunyai spektrum yang sangat sempit. Kecepatan transmisi fiber optik sangat tinggi sehingga sangat bagus digunakan sebagai saluran komunikasi.

Perkembangan teknologi fiber optik saat ini, telah dapat menghasilkan pelemahan (attenuation) kurang dari 20 decibels $(\mathrm{dB}) / \mathrm{km}$. Dengan lebar jalur (bandwidth) yang besar sehingga kemampuan dalam mentransmisikan data menjadi lebih banyak dan cepat dibandingan dengan penggunaan kabel konvensional. Dengan demikian fiber optik sangat cocok digunakan terutama dalam aplikasi sistem telekomunikasi. Pada prinsipnya fiber optik memantulkan dan membiaskan sejumlah cahaya yang merambat didalamnya. Efisiensi dari fiber optik ditentukan oleh kemurnian dari bahan penyusun kaca. Semakin murni bahan kaca, semakin sedikit cahaya yang diserap oleh fiber optic [1].

\section{B. Jenis Kabel Fiber Optik}

Fiber optik dibedakan menjadi dua jenis yang didasarkan pada mode transmisinya. Adapun jenis fiber optik yaitu :

\section{Single Mode}

Fiber optik dengan inti (core) yang sangat kecil (biasanya sekitar 8,3 mikron), diameter intinya sangat sempit mendekati panjang gelombang sehingga cahaya yang masuk ke dalamnya tidak terpantul-pantul ke dinding selongsong (cladding). Bagian inti fiber optik single mode terbuat dari bahan kaca silica $(\mathrm{SiO} 2)$ dengan sejumlah kecil kaca germania $(\mathrm{GeO} 2)$ untuk meningkatkan indeks biasnya. Untuk mendapatkan performa yang baik pada kabel ini, biasanya untuk ukuran selongsongnya adalah sekitar 15 kali dari ukuran inti (sekitar 125 mikron). Kabel untuk jenis ini paling mahal, tetapi memiliki pelemahan kecil (kurang dari $0.35 \mathrm{~dB}$ per kilometer), sehingga memungkinkan kecepatan yang sangat tinggi dari jarak yang sangat jauh.
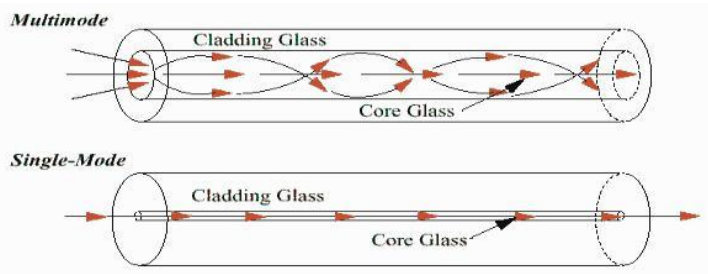

Gambar 1. Single Mode

\section{Multi Mode}

Kabel fiber optik multi mode merupakan kabel yang dapat mentransmisikan banyak cahaya dalam waktu bersamaan karena memiliki ukuran inti besar yang memiliki diameter sekitar 62,5 mikrometer. Kabel jenis ini biasanya digunakan untuk keperluan komersial yang pada umumnya diakses banyak orang. Fiber optik ini mengirimkan sinar inframerah yang memiliki panjang 850-1300 nanometer.
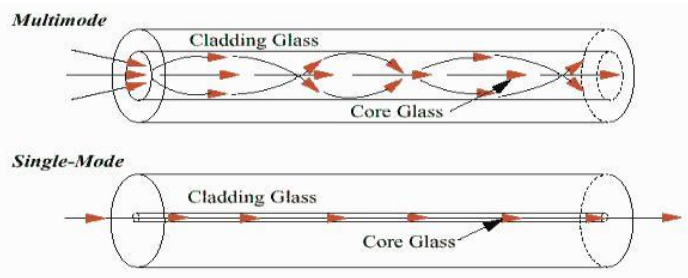

Gambar 2. Multi Mode

\section{Bagian Pada Fiber Optik}

Fiber optik terdiri dari beberapa bagian yang memiliki fungsi masing-masing. Berikut ini adalah beberapa bagian kabel fiber optik:

\section{Bagian Inti (core)}

Bagian inti fiber optik terbuat dari bahan kaca dengan diameter yang sangat kecil (diamaternya sekitar $2 \mu \mathrm{m}$ sampai $50 \mu \mathrm{m})$. Diameter fiber optik yang lebih besar akan membuat performa yang lebih baik dan stabil.

\section{Bagian Cladding}

Bagian cladding adalah bagian pelindung yang langsung menyelimuti fiber optik. Biasanya ukuran cladding ini berdiameter $5 \mu \mathrm{m}$ sampai $250 \mu \mathrm{m}$. Cladding terbuat dari bahan silikon dan komposisi bahannya berbeda dengan bagian core. Selain melindungi core, cladding juga berfungsi sebagai pemandu gelombang cahaya yang merefleksikan semua cahaya tembus kembali kepada core.

\section{Bagian Coating / Buffer}

Bagian coating adalah mantel dari fiber optik yang berbeda dari cladding dan core. Lapisan coating ini terbuat dari bahan plastik yang elastis. Coating berfungsi sebagai lapisan pelindung dari semua gangguan fisik yang mungkin terjadi, misalnya lengkungan pada kabel dan kelembaban udara dalam kabel.

\section{Bagian Strength Member \& Outer Jacket}

Lapisan ini merupakan bagian yang sangat penting karena menjadi pelindung utama dari sebuah kabel fiber optik. Lapisan strength member dan outer jacket adalah bagian terluar dari fiber optik yang melindungi inti kabel dari berbagai gangguan fisik secara langsung.

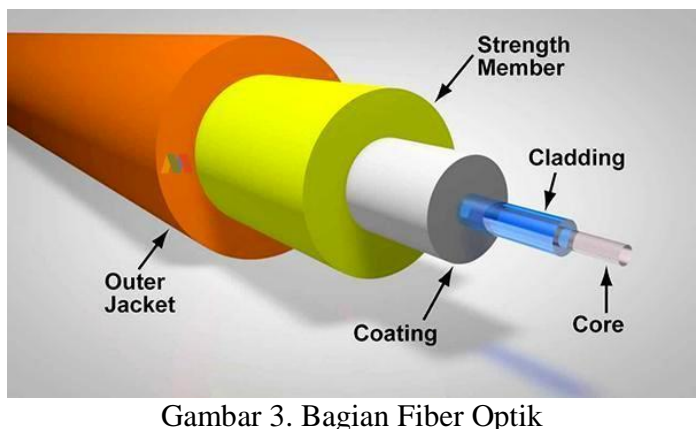

\section{Kode Warna Fiber Optik}

Struktur kabel fiber optik berbeda dengan kabel multipair tembaga, jika pada kabel tembaga dikenal istilah pasangan atau pair, maka pada kabel fiber optik tidak dikenal istilah pasangan atau pair. Secara umum, 
struktur kabel fiber optik terdiri dari tube dan fiber (atau istilah umumnya dilapangan disebut dengan "core"). Pada tube dan core untuk mengenali urutan diberi warna yang berbeda.Sesuai dengan standard TIA/EIA-598 yang dipakai secara internasional, digunakan 12 warna sebagai pengenal urutan, yaitu : BIRU, ORANGE, HIJAU, COKELAT, ABU-ABU, PUTIH, MERAH, HITAM, KUNING, UNGU, PINK, dan TOSCA.

Untuk menghafal biasanya menggunakan kata kunci "BOHCAP MHKUPT". Pada setiap tube maksimum berisi 12 fiber atau core, yang dimulai dari warna biru sampai dengan toska, dan setiap kabel maksimum berisi 12 tube, sehingga total dalam satu kabel maksimum berisi 144 fiber atau core. Suatu kabel fiber optik dengan 12 tube dan setiap tube berisi 12 fiber optik, maka warna dan urutan core atau fiber optik adalah sebagai berikut :

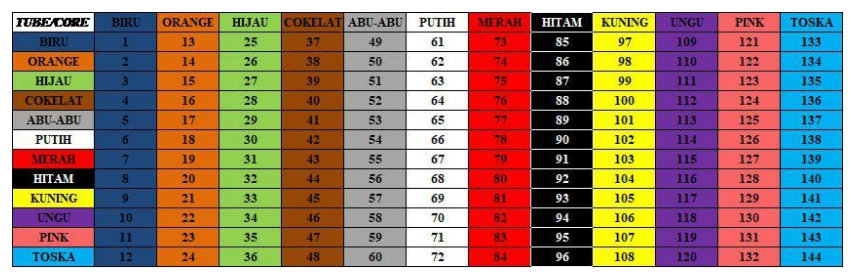

Gambar 4. Urutan Warna 144 Core

\section{E. Optical Line Terminal (OLT)}

Optical Line Terminal adalah jenis perangkat aktif yang merupakan sub sistem dari Optical Access Network yang berdasarkan terknologi Passive Optical Network, berfungsi sebagai antarmuka sental dengan jaringan yang dihubungkan ke satu atau lebih jaringan distribusi optik.

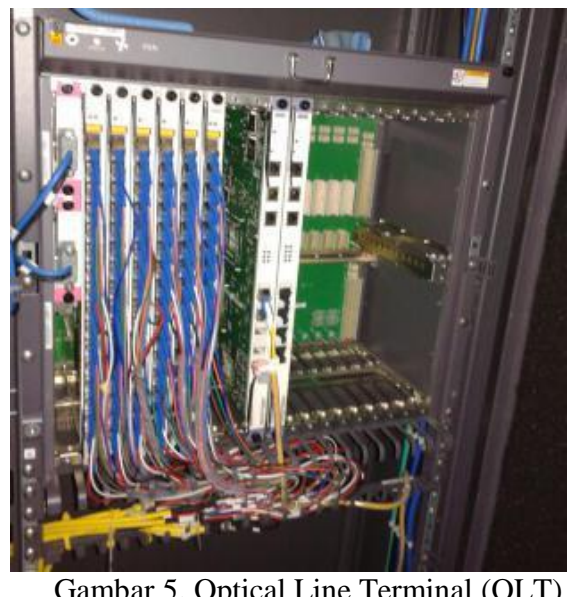

\section{F. Optical Distribution Frame (ODF)}

Optical Distribution Frame berfungsi sebagai titik terminasi kabel fiber optic, sebagai tempat peralihan dari kabel fiber optic outdoor dengan kabel fiber optic indoor dan sebaliknya. Fungsi lainnya sebagai titik koneksi perangkat ke Optical Digital Network ( ODN ) dan sebagai titik cross connect antara ODF. Wujud dari ODF adalah berbentuk rak dan dipasang di sisi STO.

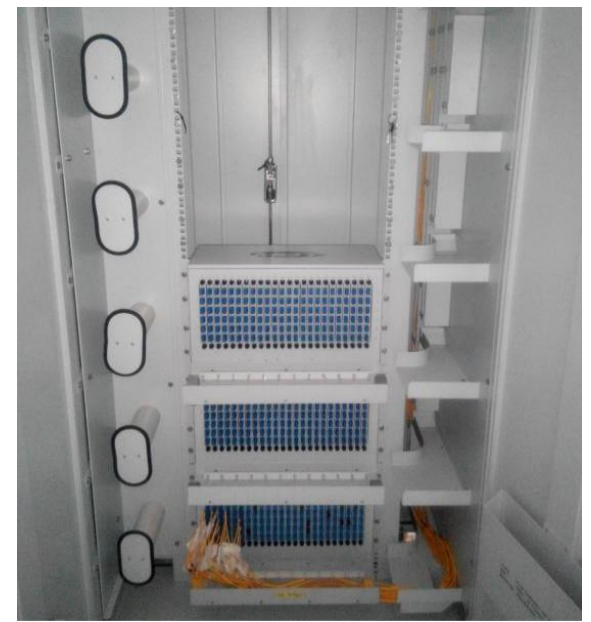

Gambar 6. Optical Distribution Frame

\section{G. Optical Distribution Cabinet (ODC)}

Optical Distribution Cabinet adalah perangkat pasif yang di instalasi diluar STO, pemasangan ODC biasa dilakukan dilapangan (Outdoor). ODC mempunyai fungsi sebagai berikut :

a. Sebagai titik terminasi ujung kabel feeder dan kabel distribusi.

b. Sebagai titik distribusi kabel feeder menjadi beberapa kabel distribusi.

c. Tempat pemasangan splitter.

d.

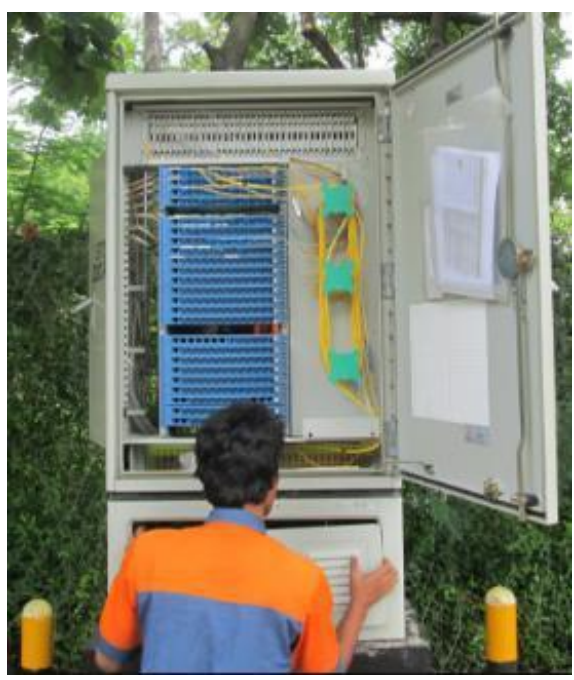

Gambar 7. Optical Distribution Cabinet (ODC)

\section{METODE PENELITIAN}

Metode penelitian yang tepat akan menghasilkan data-data yang akurat dan terpercaya. Data-data yang akurat dan terpercaya sangat diperlukan untuk penyusunan suatu laporan yang baik dan benar. Guna mencapai hal tersebut, penulis menggunakan metode penelitian sebagai berikut :

\section{Objek Penelitian}

Objek yang digunakan adalah jaringan dan komponen FTTH milik Telkom.

\section{Sumber Data}


Data-data yang penulis gunakan sebagai bahan penyusunan laporan ini berdasarkan sumbernya, secara garis besar dapat dibagi menjadi 2 kelompok :

a. Data Primer, adalah semua data yang bersumber langsung dari objek penelitian di lapangan.

b. Data Sekunder, adalah semua data yang bersumber selain dari objek penelitian di lapangan. Data ini penulis peroleh misalnya dari instruksi kerja, dokumen spesifikasi peralatan, buku literatur terkait dan sumber-sumber lainnya.

\section{Metode Pengumpulan Data}

Sedangkan metode pengumpulan data yang penulis terapkan antara lain :

a. Studi Lapangan, merupakan studi secara langsung terhadap objek penelitian melalui 2 cara:

1) Metode Wawancara, dengan cara melakukan tanya-jawab secara langsung terhadap pembimbing lapangan yang kompeten yang ditunjuk oleh pihak PT. Telkom Akses.

2) Metode Pengamatan, dengan cara melakukan pengamatan secara langsung terhadap objek penelitian serta membandingkan kebenarannya dengan data-data yang diperoleh melalui metode wawancara dan studi pustaka.

b. Studi Kepustakaan, merupakan studi secara tidak langsung terhadap objek penelitian melalui penelaahan dan pengkajian data-data pendukung dari bukubuku literatur maupun dari sumber-sumber lainnya seperti dokumen standar internasional terkait, artikel-artikel dari sumber terpercaya serta tidak menutup kemungkinan dari halaman situs yang dapat dipercaya kebenarannya.

\section{HASIL DAN PEMBAHASAN}

\section{Fiber To The Home (FTTH)}

Fiber to The Home (disingkat FTTH) merupakan suatu format penghantaran isyarat optik dari pusat penyedia (provider) ke kawasan pengguna dengan menggunakan fiber optik sebagai medium penghantarnya. Perkembangan teknologi ini tidak terlepas dari kemajuan perkembangan teknologi fiber optik yang dapat mengantikan penggunaan kabel konvensional, serta didorong juga oleh keinginan untuk mendapatkan layanan yang dikenal dengan istilah Triple Play. Triple Play Services adalah layanan berbasis fiber optik yang mana akan mendapatkan akses internet yang cepat, suara (jaringan telepon), dan video (TV kabel) dalam satu infrastruktur pada unit pelanggan.[2]

Penghantaran dengan menggunakan teknologi FTTH ini dapat menghemat biaya dan mampu mengurangkan biaya operasi serta memberikan pelayanan yang lebih baik kepada pelanggan. Ciri-ciri inheren fiber optik membenarkan penghantaran isyarat telekomunikasi dengan lebar jalur (bandwidth) yang lebih besar dibandingkan dengan penggunaan kabel konvensional.

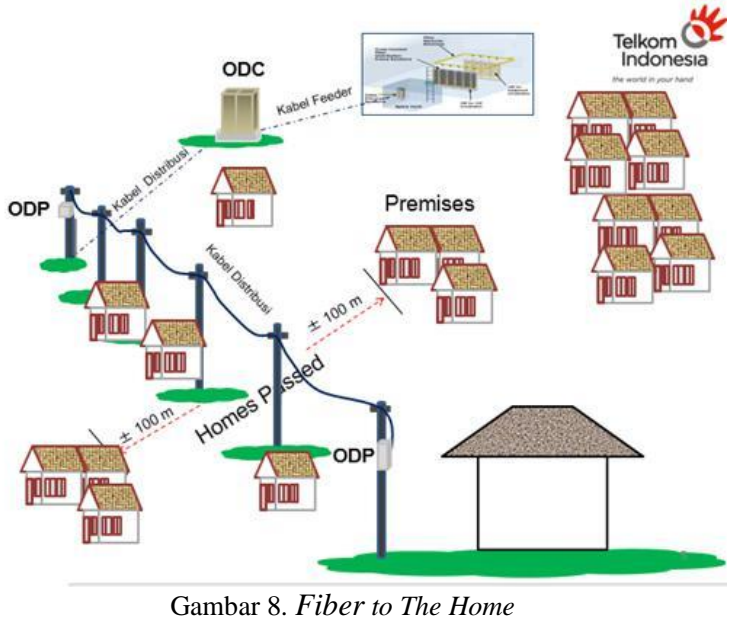

2. Perangkat FTTH

a. Metro Ethernet (ME/Metro-E)

Jaringan Metro Ethernet, memiliki arti kata yaitu jaringan komunikasi data yang berskala metro atau besar yang mencakup skala perkotaan, dengan menggunakan teknologi Ethernet. Jika dilihat dengan arti sebenarnya, teknologi Metro-E merupakan salah satu pengembangan dari teknologi Ethernet yang dapat mencakup wilayah yang lebih luas dan berskala perkotaan dengan dilengkapi berbagai layanan-layanan yang terdapat pada jaringan Ethernet pada umumnya. Sehingga jaringan yang berskala metro dapat dibentuk dengan menggunakan teknologi Ethernet seperti biasanya.

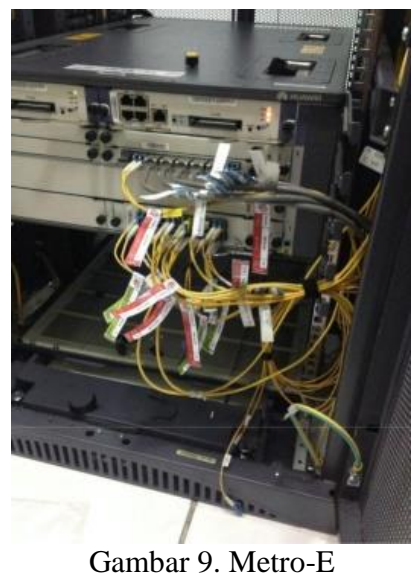

\section{b. Optical Line Termination (OLT)}

Optical Line Termination (OLT) adalah perangkat yang berfungsi sebagai titik akhir (end-point) dari layanan jaringan optik pasif (Passive Optical Network / PON). Perangkat ini mempunyai dua fungsi utama, yaitu:

1) Melakukan konversi antara sinyal listrik dan sinyal optik.

2) Mengkoordinasikan multiplexing pada perangkat lain di ujung jaringan yang biasa disebut dengan Optical Network Terminal (ONT) atau Optical Network Unit (ONU). 
OLT merupakan penyedia interface antara sistem PON dengan penyedia layanan (service provider) data, video dan telepon.

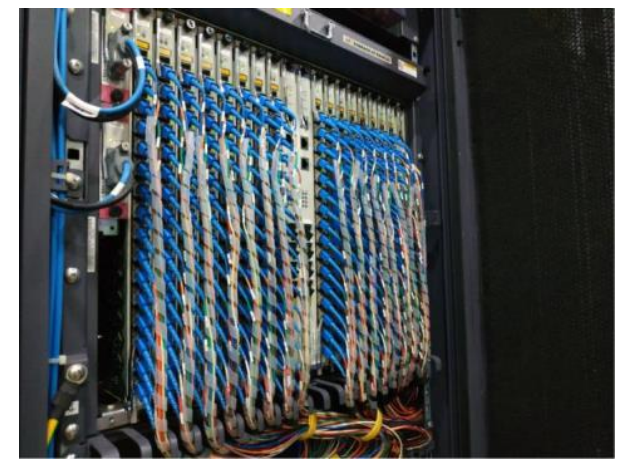

Gambar 10. Optical Line Termination (OLT)

\section{c. Optical Distribution Frame (ODF)}

Merupakan titik terminasi kabel fiber peralihan dari kabel fiber optik outdoor dengan kabel fiber optik indoor dan sebaliknya.
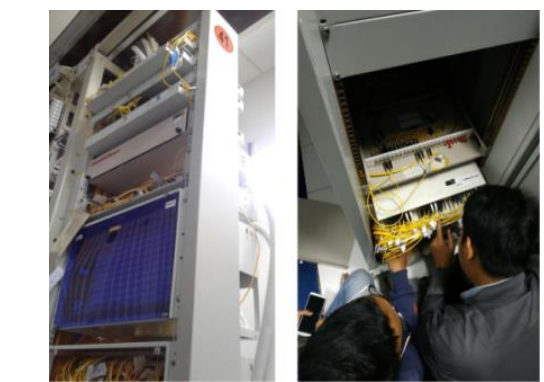

Gambar 11. Optical Distribution Frame (ODF)

\section{d. Frame Termination Management (FTM)}

Merupakan infrastruktur jaringan akses berbasis fiber optik khususnya jaringan akses FTTH yang berada di posisi central office. Perangkat FTM berfungsi sebagai manajemen terminasi kabel optik pada jaringan akses dan crossconnect serta interconnection patchcord antar O-Akses, E-Akses, dan E-Trans.

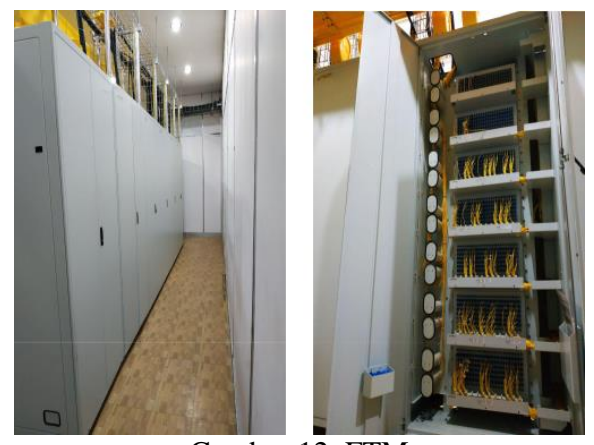

Gambar 12. FTM

\section{e. Optical Distribution Cabinet (ODC)}

Perangkat outdoor dalam jaringan akses FTTH yang pertama adalah Optical Distribution Cabinet (ODC). ODC adalah suatu ruang yang berbentuk kotak atau kubah (dome) yang terbuat dari material khusus yang berfungsi sebagai tempat instalasi sambungan jaringan optik single-mode, yang berisikan connector, splicer, maupun splitter dan dilengkapi ruang manajemen fiber dengan kapasitas tertentu pada jaringan akses optik pasif (Passive Optical Network / PON). ODC berfungsi sebagai tempat terminasi antara kabel feeder dengan kabel distribusi. Dapat disimpulkan bahwa di dalam ODC terdapat splitter dari sentral atau OLT yang nantinya akan dibagi ke ODP.

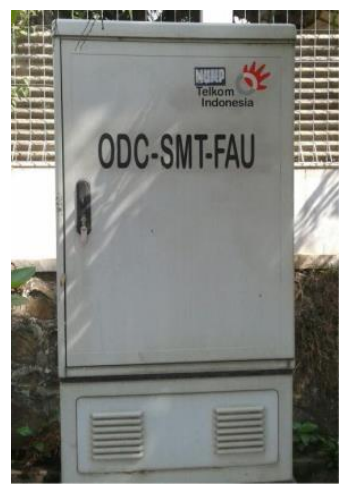

Gambar 13. Optical Distribution Cabinet (ODC)

\section{f. Optical Distribution Point (ODP)}

Optical Distribution Point (ODP) merupakan perangkat terminasi awal penggunaan drop cable, sebelum masuk ke rumah pelanggan. Ada tiga jenis ODP, yaitu ODP Pedestal, ODP Pole, dan ODP Closure. Komponen perangkat ODP terdiri dari optical pigtail, connector adaptor, splitter room, ruang manajemen fiber dengan kapasitas tertentu dan dilengkapi dengan tempat untuk jalur masuk dan keluar kabel (kabel distribusi dan drop).[3]

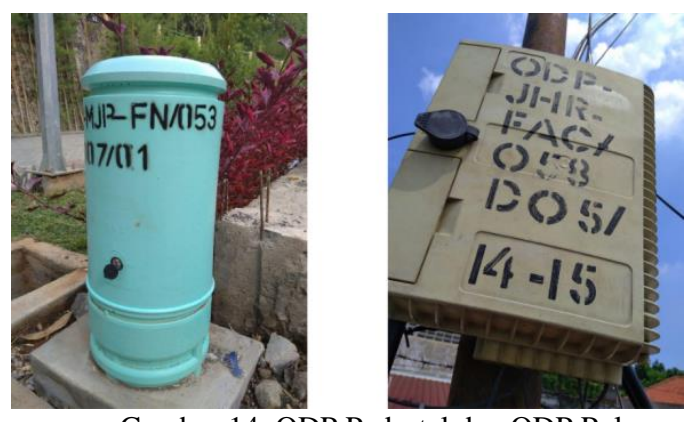

Gambar 14. ODP Pedestal dan ODP Pole

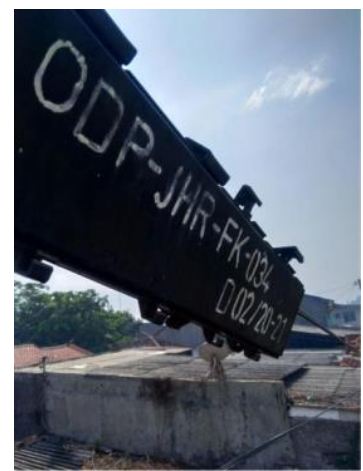

Gambar 15. ODP Closure 


\section{g. OTP atau Roset}

OTP (Optical Termination Premises) / Roset merupakan perangkat pasif yang diletakkan di rumah pelanggan, yang menjadi titik terminasi akhir dari kabel indoor / dropcore fiber optik.

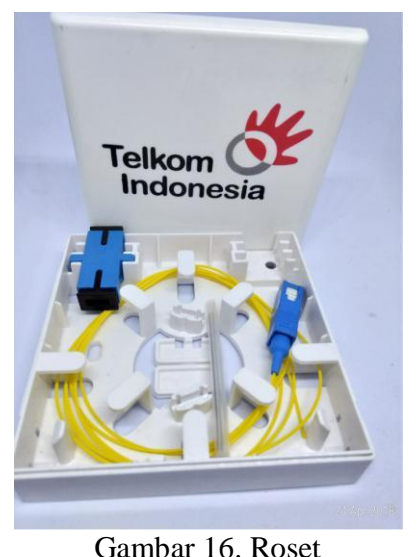

\section{h. Optical Network Terminal (ONT)}

ONT adalah perangkat yang akan terhubung langsung dengan perangkat milik pelangggan. Port (RJ11 dan RJ45) output dari ONT biasanya terhubung dengan kabel UTP ke fixed telephone, router wireless, PC maupun decoder TV. Hal yang perlu diperhatikan adalah posisi ONT harus dekat dengan stop kontak listrik karena suplai power ONT dari PLN/listrik.

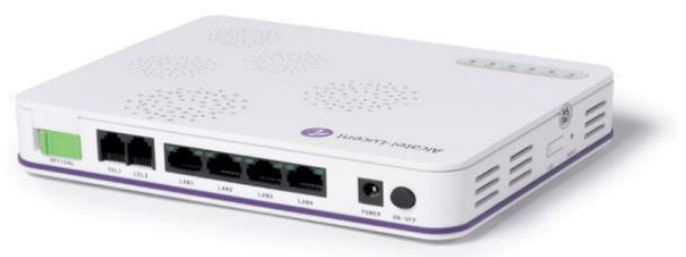

Gambar 17. ONT

\section{Segmentasi Jaringan FTTH}

Secara umum jaringan FTTH dapat dibagi menjadi 4 segmen catuan kabel selain perangkat aktif seperti OLT dan ONU/ONT, yaitu sebagai berikut ;

1) Segmen A : Catuan kabel Feeder

2) Segmen B : Catuan kabel Distribusi

3) Segmen C : Catuan kabel Dropcore

4) Segmen D : Catuan kabel Rumah

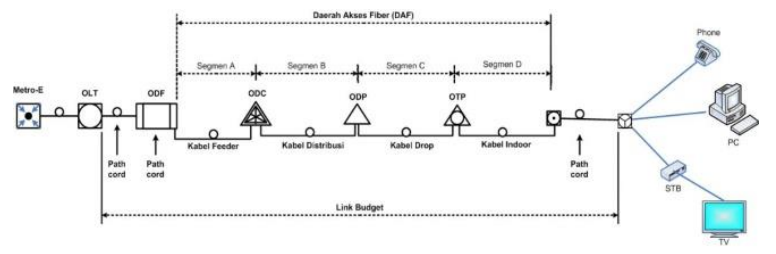

Gambar 18. Topologi FTTH

Segmen A, kabel feeder adalah kabel optik yang menghubungkan antara 2 perangkat yaitu ODF/FTM di sisi STO dan di ODC di sisi outdoor. Kabel feeder yang keluar dari STO minimal kapasitas 96 core baik untuk sistem duct maupun aerial.

Segmen B, kabel distribusi adalah kabel optik yang menghubungkan antara 2 perangkat outdoor yaitu ODC dan ODP. Kabel distribusi yang keluar dari ODC biasanya berkapasitas 12-24 core baik sistem duct maupun aerial.

Segmen C, kabel dropcore adalah kabel optik yang menghubungkan antara 2 perangkat yaitu ODP di sisi outdoor dan di OTP di sisi rumah pelanggan. Kabel dropcore yang masuk ke rumah pelanggan biasanya berkapasitas 1-2 core baik untuk sistem duct maupun aerial.

Segmen D, kabel rumah / kabel indoor adalah kabel optik yang menghubungkan antara 2 perangkat yaitu OTP dan Roset di sisi rumah pelanggan

\section{Konfigurasi FTTH}

Konfigurasi jaringan akses fiber FTTH sama hal seperti pada jaringan akses tembaga dimana terdapat segmen - segmen catuan.[4] Desain jaringan fiber optik milik Telkom dapat dilihat pada Gambar 4.20 dimana sudah digambarkan bagaimana ONT dapat terhubung dengan OLT. Melalui beberapa perangkat untuk ONT dapat terhubung ke OLT. Mulai dari ONT ke Roset dihubungkan menggunakan kabel patchcord kemudian dari Roset menuju ke OTP menggunakan kabel indoor lalu dari OTP menuju ke ODP yang berada di luar rumah dihubungkan menggunakan kabel dropcore. ODP itu sendiri merupakan hasil pembagian kabel distribusi/kabel udara yang menuju ke ODC. Lalu dari ODC menuju STO/FTM/ODF menggunakan kabel feeder.[5]

Pada desain jaringan ini, passive splitter dipasang pada ODC dan ODP. Untuk passive splitter yang dipasang di ODC menggunakan splitter 1:4 sedangkan pada ODP menggunakan splitter 1:8. Pemilihan jenis splitter ini sudah diperhitungkan sebelumnya dan sudah disesuaikan dengan standar instalasi untuk GPON.

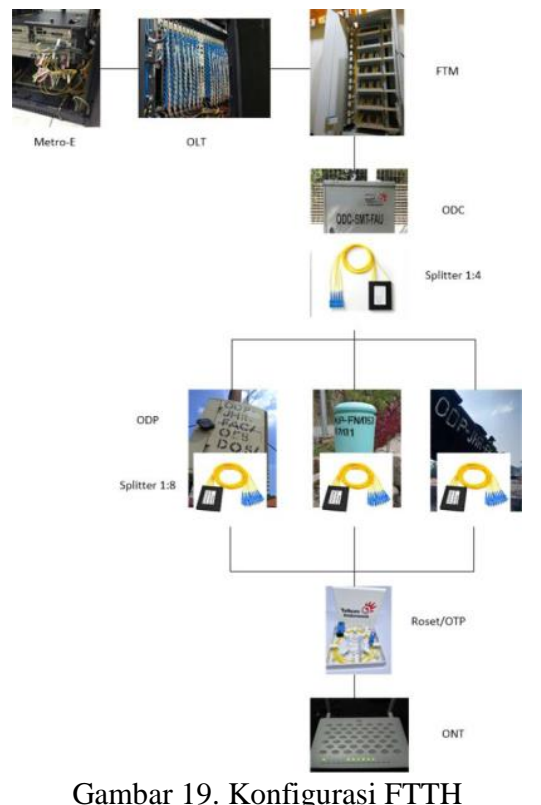

Gambar 19. Konfigurasi FTTH 


\section{Link Budget}

Link Budget adalah cara untuk menghitung penguatan dan redaman dari semua parameter yang dibutuhkan untuk membangun suatu jaringan seperti jaringan FTTH. Perhitungan link budget atau total Loss adalah perhitungan standar total redaman pada FTTH untuk mengetahui layak atau tidaknya jaringan FTTH diimplementasikan pada jaringan sebenarnya.[6] Dimana perhitungan dari Link Budget ini dapat memaksimalkan hasil dari arsitektur jaringan yang akan dibuat. Parameter yang dihitung dalam rumus perhitungan Link Budget dapat berupa penguatan (gain) dan redaman (loss).

Rumus untuk menghitung Link Budget berasal dari hasil perhitungan dari gain (penguatan) dan loss (rugirugi) yang ada pada suatu pemancar. Gain dapat berasal dari amplifier sedangkan loss dapat disebabkan oleh konektor, media penghantar (kabel, udara, dll), dan dapat pula berasal dari proses instalasi.

Tabel 1. Standar Redaman

\begin{tabular}{|c|c|c|c|c|c|c|}
\hline No & \multicolumn{2}{|c|}{ Uraian } & Satuan & $\begin{array}{c}\text { Standar } \\
\text { Redaman } \\
\text { (dB) }\end{array}$ & $\begin{array}{l}\text { Vol- } \\
\text { ume }\end{array}$ & $\begin{array}{c}\text { Total } \\
\text { Redaman } \\
(\mathrm{dB})\end{array}$ \\
\hline 1 & \multicolumn{2}{|c|}{ Kabel FO } & $\mathrm{km}$ & 0,35 & 17 & 5,95 \\
\hline \multirow{5}{*}{2} & \multirow{5}{*}{$\begin{array}{l}\text { Split- } \\
\text { ter }\end{array}$} & $1: 2$ & bh & 3,7 & - & - \\
\hline & & $1: 4$ & bh & 7,25 & 1 & 7,25 \\
\hline & & $1: 8$ & bh & 10,38 & 1 & 10,38 \\
\hline & & $1: 16$ & bh & 14,10 & - & - \\
\hline & & $1: 32$ & bh & 17,45 & - & - \\
\hline \multirow{2}{*}{3} & \multirow{2}{*}{$\begin{array}{l}\text { Kon- } \\
\text { ektor }\end{array}$} & SC/UPC & bh & 0,25 & 5 & 1,25 \\
\hline & & SC/APC* & bh & 0,25 & 2 & 0,5 \\
\hline \multirow{3}{*}{4} & \multirow{3}{*}{$\begin{array}{l}\text { Sam- } \\
\text { bun- } \\
\text { gan }\end{array}$} & $\begin{array}{c}\text { Di Kabel } \\
\text { Feeder }\end{array}$ & bh & 0,10 & 3 & 0,3 \\
\hline & & $\begin{array}{l}\text { Di Kabel } \\
\text { Distribusi }\end{array}$ & bh & 0,10 & 2 & 0,2 \\
\hline & & $\begin{array}{l}\text { Di Drop } \\
\text { Cable }\end{array}$ & bh & 0,10 & 2 & 0,2 \\
\hline \multicolumn{6}{|c|}{ TOTAL REDAMAN MURNI } & 26,03 \\
\hline
\end{tabular}

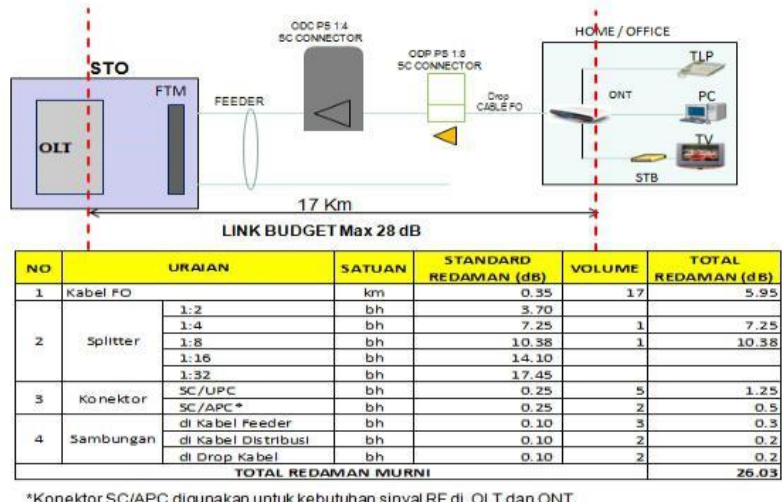

Gambar 20. Perhitungan Link Budget

Perhitungan Link Budget ini sangat penting dalam suatu perancangan jaringan karena dengan Link Budget dapat mengetahui seberapa besar daya yang akan dipancarkan oleh pemancar agar dapat diterima dengan baik di sisi penerima.

Maksimal redaman yang ada pada jaringan FTTH ini tidak boleh lebih dari $28 \mathrm{~dB}$, karena daya yang dapat diterima oleh sensitivitas ONT berkisar antara $8 \mathrm{dBm}$ s/d -28 dBm. Semakin kecil redaman yang ada, maka semakin besar daya dari OLT yang akan diterima oleh ONT dan menunjukkan bahwa jaringan tersebut telah memenuhi standar.

\section{KeSIMPULAN}

Berdasarkan pembahasan yang telah penulis uraian tentang analisa konfigurasi jaringan FTTH pada layanan Indihome, dapat disimpulkan sebagai berikut:

1. Fiber optik adalah salah satu media transmisi tercepat, menghantarkan informasi jarak jauh tanpa pengulangan (repeater).

2. Migrasi Jaringan dari tembaga ke fiber optic sangat berguna untuk mendukung kemajuan teknologi dikarenakan dengan menggunakan media transmisi berbasis serat optik maka kecepatan dalam mengirim dan menerima data juga semakin cepat dibandingankan dengan kabel tembaga.

3. FTTH merupakan teknologi yang tepat untuk memenuhi kebutuhan di era digital seperti saat ini. Pelanggan dapat menikmati Triple Play Services dalam satu infrastruktur pada unit pelanggan.

4. Jaringan FTTH sangat efektif dipakai, karena kita bisa menggunakan layanan triple play (telepon, internet dan IPTV) hanya dengan 1ONT/ modem saja disisi pelanggan

5. Terdapat 4 segmen pada jaringan FTTH, segmen A adalah catuan kabel feeder, segmen B adalah catuan kabel distribusi, segmen $\mathrm{C}$ adalah catuan kabel dropcore, dan segmen D adalah catuan kabel rumah.

6. Dalam instalasinya harus memerhatikan faktor penyebab Loss agar daya atau gain tetap di berada pada sensitifitas ONT yaitu antara $-8 \mathrm{dBm} \mathrm{s} / \mathrm{d}-28$ $\mathrm{dBm}$.

\section{DAFTAR PUSTAKa}

[1] Dwi Agus Priyanto dan Eka Wahyudi. 2014. Perancangan Modernisasi Migrasi Jaringan Dari Kabel Tembaga ke Kabel Serat Optik di Perumahan Dian Anugerah Regency Gambut Kabupaten Banjar, Kalimantan Selatan. Purwokerto: Jurnal Program Studi DIII Sekolah Tinggi Teknologi Telematika Purwokerto. Sekolah Tinggi Teknologi Telematika Telkom.

[2] Alfarizi M, Rosmiati M, Mutiara GA. 2015. Pembuatan Desain Jaringan Fiber To The Home (FTTH) Pada Perumahan Buah Batu Square Bandung. e-Proceeding of Applied Science Vol. 1 No.2

[3] PT TELEKOMUNIKASI INDONESIA Tbk.," Pedoman Pemasangan Jaringan Fiber to the Home (PPJ FTTH)", Bandung : 30 Desember 2013.

[4] PT TELEKOMUNIKASI INDONESIA Tbk.,'Desain Jaringan FTTH", Hernady. Joddy, Bandung : 30 Desember 2013.

[5] PT TELEKOMUNIKASI INDONESIA Tbk.,"Pedoman Pemasangan Jaringan Telekomunikasi PPJT 2000-I ( 
JARLOKAT )", Setiawan. Suryatin, Bandung : 18 Desember 2000.

[6] Yanuardin M I, Devie R S, Mia R S. 2016. Perancangan Jaringan FTTH (Fiber To The Home). e-Proceeding of Applied Science, Vol. 2 No. 1 